Rojabi Az̧arghany

\title{
KONSUMSI YANG SAKRAL: \\ Amalan dan Air Doa sebagai Terapi Religius \\ Di Probolinggo
}

Universitas Nurul Jadid, Probolinggo

Email: azharghany@unuja.ac.id

Received:

2020-03-10

Received in revised form:

2020-04-09

Accepted:

2020-06-24

Citation:

Azharghany, Rojabi.

(2020), Konsumsi Yang-

Sakral: Amalan Dan Air

Doa Sebagai Terapi

Religius Di Probolinggo

7(1), 138-178.

\begin{abstract}
The practice of the ritualprayer waterand amalan by asking the kiai which is the belief of the community is constructed as a sacred bouse that can calm their spirituality from the blazing confusion and problems of life. This study aims to find out how the role of the kiai as religious leaders and social leaders in maintaining the spirituality of the people through water rituals of prayer and practice. This study takes the setting of a kiai in Pesantren Nurul Jadid who has the highest number of students in Probolinggo, East Java. The construction of the community of prayer water and practices are assessed using qualitative methods. Researchers chose non-probability sampling techniques by determining the subject in a purposive and snow ball manner. Collecting data with participant observation and interviewing 1 kiai and 8 communities around pesantren who have special needs for prayer and practice water. The data analysis of this study uses the concept approach of Berger's knowledge sociology. The results of the analysis of community construction in the pesantren indicate their need for supernatural power to solve life's problems. The community identifies this power with the kiai. It is this identity that maintains and maintains the social structure of the relationship between the community and the kiai to the present, as well as being externalized by the kiai in conducting spiritual guidance.
\end{abstract}

Keywords: Kiai, Prayer Water and Amalan, Social Construction 


\begin{abstract}
Abstrak: Praktik ritual air doa dan amalan dengan meminta pada kiai yang menjadi keyakinan masyarakat dikonstruksi sebagai rumah suci yang dapat menedubkan spiritualitas mereka dari terik. kebingungan dan persoalan bidup. Studi ini bertujuan untuk mengetahui bagaimana peran kiai sebagai religious leader dan social leader dalam menjaga spiritualitas umat melalui ritual air doa dan amalan. Penelitian ini mengambil setting kiai di Pesantren Nurul Jadid yang memiliki jumlah santri terbanyak di Probolingoo Jawa Timur. Konstruksi masyarakat terhadap air doa dan amalan tersebut dikaji dengan menggunakan metode kualitatif. Peneliti memilih teknik sampling non probability dengan penentuan subjek secara purposive dan snow ball. Pengumpulan data dengan participant observation dan mewawancarai 1 kiai dan 8 masyarakat sekitar pesantren yang berkebutuban khusus terbadap air doa dan amalan. Analisa data kajian ini menggunakan pendekatan konsep sosiologi pengetahuan Berger. Hasil dari analisa konstruksi masyarakat yang ada di lingkungan Pesantren menunjukkan kebutuban mereka terhadap kekuatan adikodrati untuk penyelesaian persoalan bidup. Masyarakat mengidentitaskan kekuatan itu pada kiai. Identitas inilah yang menjaga dan memelihara struktur sosial bubungan antara masyarakat dan kiai bingga saat ini, sekaligus dieksternalisasi oleh kiai dalam melakukan bimbingan spiritual.
\end{abstract}

Kata kunci: Kiai, Air Doa dan Amalan, Konstruksi Sosial.

\title{
PENDAHULUAN
}

Praktik ritual air doa dan amalan dengan meminta pada kiai yang menjadi keyakinan masyarakat Jawa Timur, khususnya yang tinggal di sekitar pesantren dikonstruksi sebagai rumah suci yang dapat meneduhkan spiritualitas mereka dari terik kebingungan dan persoalan hidup. Kiai sebagai tuan rumah suci tersebut memandang kayakinan masyarakat dalam tradisi air doa dan amalan menjadi faktor yang cukup penting dalam proses kiai melakukan bimbingan dan menjaga spritualitas masyarakat agar sesuai dengan makna hidup yang dikonstruksi oleh kiai. ${ }^{1}$

Apa yang akan kita cermati dari ritual air doa dan amalansejatinya terbilang wajar dan cukup lumrah dikalangan pesantren maupun dilingkungan masyarakat yang hidup dan mendapatkan pengaruh dari aktivitas pesantren

${ }^{1}$ Rojabi Azharghany, 'Capitalizing The Sacred: Marketing Blessed Water as Religious Theraphy in Krejengan Probolinggo', AT-TUR AS: Jurnal Studi Keislaman, 5.2 (2018) hal 97. 
ataupun masyarakat yang berada disekitar pesantren. Sebuah tradisi yang hampir setiap hari bisa kita jumpai dimana santri, wali santri, masyarakat sekitar, maupun masyarakat dari luar kota datang kepada kiai di pesantren untuk meminta air doa maupun amalan dengan berbagai macam keperluan.

Air Doa adalah air yang telah diberi bacaan-bacaan khusus oleh kiai. Air tersebut bukanlah air khusus karena bisa diambilkan dari mana saja. Sedangkan amalanadalah bacaan-bacaan maupun ritual khusus yang diberikan oleh kiai dengan menyesuaikan terhadap kepentingan atau keperluan (bajat) dari orang yang datang kepada kiai.

Keperluan tersebut bisa ditujukan untuk dirinya maupun orang lain; misalkan seperti untuk keselamatan bayi dikandungan dan ketika melahirkan, mengharapkan anak yang soleh dan cerdas, untuk kesembuhan dari berbagai macam penyakit, mendapatkan jodoh, murah rizki, lancar perdagangan dan urusan-urusan lain yang sebenarnya saat ini sudah ada profesi yang resmi untuk menanganinya.

Namun yang perlu menjadi catatan adalah masih minimnya penelitianpenelitian yang dilakukan dalam mengungkap fakta tradisi demikian. Kebanyakan penelitian dilakukan pada wujud kebendaan yang memang telah lama dianggap suci oleh sejumlah masyarakat seperti Sumber Tempur di Mojokerto, Sumber Waras di Probolinggo, Air Sendang Mbeji di Bantul, Air Suci Candi Gereja di Bantul, Air Suci Sendang Panguripan di Sleman dan Air Suci Gua Maria di Sendangsono. Praktek tradisi demikian ini sangat berbeda secara kasat mata dalam pola yang dilakukan masyarakat dalam hal berkepentingan mendatangi kiai. Jelaslah bahwa air yang diberi doa oleh kiai tidak dalam kriteria tempat khusus dalam pengambilannya. Semua air bisa diberi doa oleh seorang kiai dan masyarakatpun bebas memilih dan membawa sendiri dari jenis air yang mana saja. Dengan demikian ini menjadi sangat berbeda dengan model "Air Yang Disucikan" oleh sejumlah masyarakat. 
Sehingga bisa jadi kedatangan masyarakat dalam rangka meminta air doa bukan karena airnya, tapi karena faktor ke-kiai-annya. Benarkah? Tentu hal ini bisa menimbulkan konsekuensi-konsekuensi lain dalam pola maknanya jika dibandingkan dengan model "Air Yang Disucikan".

Penelitian yang banyak dilakukan juga pada tempat-tempat keramat seperti makam maupun petilasan (bekas tempat singgah seorang tokoh yang ditahbiskan oleh kalangan masyarakat tertentu sebagai "orang suci" yang sedang menyebarkan ajaran). Tentunya ada ritual-ritual tertentu bagi orang yang memiliki tujuan khusus (bukan dalam rangka berwisata) yang dilakukan ditempat keramat tersebut. Pemandangan demikian tidak akan kita dapatkan pada masyarakat yang meminta air doa maupun amalan pada kiai. Toh kalaupun ada ritual khusus akan dilakukan tidak dihadapan kiai.

Dalam hal memberikan pelayanan kepada masyarakat dengan berbagai kepentingan, layak jika dibedakan antara kiai dengan dukun ataupun orang pintar. Walaupun ada sejumlah kiai yang oleh masyarakat tertentu dianggap sebagai kiai juga dukun. Namun yang menjadi kajian kita disini adalah pada kiai yang oleh masyarakat tidak dianggap sebagai dukun, bahkan menyebutnya dukun adalah hal yang tabu, tapi kiai tersebut tetap dijadikan rujukan dalam mengadukan berbagai persoalan-persoalan yang ada. Lalu, makna apa sebenarnya yang ada dalam pikiran masyarakat jika kedatangannya pada kiai yang tidak dianggap sebagai dukun atau "orang pintar" apalagi sebagai profesi ahli?

Kenyataannya memang masyarakat-terutama Jawa timur-yang hidup dengan pengaruh pesantren memiliki daya tarik yang kuat terhadap sosok yang disebut kiai. Kiai sebagai pemimpin Islam, adalah orang yang diyakini masyarakat mempunyai otoritas yang sangat besar dan kharismatik. ${ }^{2}$

\footnotetext{
${ }^{2}$ Hoirun Nahdiyah, 'Menggugah Keberadaan Pesantren Untuk Membangun Nalar Pendidikan Berbasis Local Wisdom: Suatu Tela'ah Eksploratif Dalam Perspektif Budaya', AT-TURAS: Jurnal Studi Keislaman, 4.2 (2017).
} 
Hal ini karena kiai adalah orang suci yang dianugerahi berkah, karena tipe otoritas ini berada di luar dunia kehidupan rutin dan profan sehari-hari. Sehingga kiai dipandang mempunyai kelebihan yang luar biasa yang membuat kepemimpinannya diakui secara umum. ${ }^{3}$ Disamping kelebihan personalnya otoritas kiai dan hubungan akrabnya dengan anggota masyarakat telah dibentuk oleh kepedulian dan otoritas pada kepentingan-kepentingan umat Islam. Hubungan yang dekat antara masyarakat tersebut dengan kiai menempatkan kiai pada posisi sebagai penerjemah yang memberikan penjelasan dalam konteks Agama. ${ }^{4}$ Kiai menjadi salah satu elit strategis dalam masyarakat karena ketokohannya sebagai figur yang memiliki pengetahuan luas dan mendalam mengenai ajaran Islam. Lebih dari itu, secara teologis ia juga dipandang sebagai sosok waratsatul-anbiya, dalam pengertianulama adalah pewaris Nabi dan yang diwariskan Nabi adalah akidah, ibadah, akhlak dan berani menanggung resiko, dakwahnya aktif, dilakukan hanya karena Allah bukan yang lain. Peran kiai yang menyentuh hampir semua relung kehidupan masyarakat sangat dirasakan oleh masyarakat, dan pelayanan yang dilakukan kiai sangat sulit dilakukan oleh sembarang orang ${ }^{5}$

Jika pernyataan diatas menjadi pandangan yang lumrah dan agaknya memang demikian bagi kalangan pesantren, lalu apa yang menjadi kepercayaan masyarakat yang begitu kuat sehingga menciptakan tradisi-yang dalam pandangan penulis-perilaku yang memposisikan kiai pada struktur diluar dimana seharusnya kiai adalah sebagai tokoh sentral dalam penyampai risalah keagamaan, bukan sebagai tokoh yang dimintai peran lebih jauh dalam menerima permintaan-permintaan masyarakat, yang dalam pandangan Durkheim dikatakan sebagai kenyataan-kenyataan yang profan?.

\footnotetext{
${ }^{3}$ Hoirun Nahdiyah, 'Menggugah Keberadaan Pesantren Untuk Membangun Nalar Pendidikan Berbasis Local Wisdom: Suatu Tela'ah Eksploratif Dalam Perspektif Budaya', AT-TURAS: Jurnal Studi Keislaman, 4.2 (2017).

${ }^{4}$ Miftahul Huda, 'Assessing The Relation Between Majority And Minority Groups (A Critical Study on the Spirit of Domination in a Heterogeneous Society)', AT-TURAS: Jurnal Studi Keislaman, 3.2 (2016).

${ }^{5}$ Sa'id Aqil Siradj, Ablus Sunnah Wal Jama'ab Dalam Lintas Sejarah (Jogjakarta: LKPSM, 1998), hal. 128.

At-Turäs: Jurnal Studi Keislaman

E-ISSN: 2460-1063, P-ISSN: 2355-567X

Volume 7, No. 1, Januari-Juni 2020
} 
Menanggapi hal ini, Mulder ${ }^{6}$ memiliki pendapat lain-meskipun pendapat ini lebih umum kepada tradisi masyarakat jawa-Mulder menyatakan bahwa dalam tradisi jawa tidak mungkin dilakukan analisa dengan menggunakan dikotomi sakral dan profan, sebagaimana yang kadang-kadang dilakukan dalam sosiologi Barat. Pemikiran jawa menekankan kesatuan hidup, dimana kondisi dari semesta direfleksikan dalam kehidupan di bumi, yang mana peristiwa-peristiwa gaib menembus pengalaman sehari-hari. Alam ghaib tampak dihuni oleh segala macam makhluk halus, yang maksud dan kekuatnnya bisa bermanfaat maupun merusak, tapi yang bisa dipastikan adalah bahwa kekuatan mereka mempengaruhi dunia nyata kehidupan. Oleh karenanya orang kemudian terpikat untuk mendapatkan berkah dari mereka yang dapat melindungi dan untuk mengembangkan potensi batin mereka.

Agaknya pendapat Mulder diatas bisa dijadikan pertimbangan. Walaupun memang pada sisi-sisi tertentu ada perubahan-perubahan keyakinan kepada makhluk halus yang dinyatakan bisa memberi berkah dalam tradisi kebatinan jawa. Lebih tepatnya adalah masyarakat pesantren bisa saja meyakini bahwa berkah itu bisa didapatkan melalui kiai, yang mana kiai adalah penghubung yang diyakini kedekatannya dengan alam ghaib terutama sang pencipta. Sehingga sangat dimungkinkan munculnya perilaku-perilaku yang membentuk struktur bahwa kiai bisa dijadikan tempat untuk mengadukan segala persoalan dengan harapan bertumpu pada kedekatannya dengan sang pencipta.

Pandangan demikian ini telah menempatkan kiai sebagai sosok yang dijunjung tinggi (pepunden) dalam kultur orang jawa. Idiom-idiom seperti "orang yang menghormati orangtua dan gurunya berarti menghormati Tuhanya" menjadi legitimasi tersendiri dikalangan mereka yang semakin memantapkan posisi kiai bukan hanya sebagai guru agama tapi juga guru laku

${ }^{6}$ Niels Mulder, Ruang Batin Masyarakat Indonesia (Yogyakarta: LKIS, 2001), hal 125. 
kehidupan7. Sosok kiai kemudian menjadi pepunden yang dikeramatkan, bahkan sampai ketika mereka meninggal dunia, ritual-ritual penghormatan kepada kiai tetap dilakukan. Kemudian tradisi ini sangat mengakar kuat dengan mewujud sebagai ajaran kebatinan dalam filosofi masyarakat kejawen.

Namun, sekali lagi perlu ditekankan disini adalah bahwa pola yang dilakukan masyarakat dalam meminta air doa dan amalan pada kiai bisa saja berbeda makna dengan tradisi jawa melalui praktik kebatinan dalam filosofi kejawennya. Bagi masyarakat kejawen, sebagaimana diungkapkan Mulder,

"Praktek religius adalah hubungan kekuatan yang ditujukan ke masa depan, tidak dalam rangka keakhiratan, tapi sebagai aktivitas untuk mendapatkan keberuntungan disaat ini dan disini. Kualitas semacam ini juga ditunjukkan oleh praktek kebatinan demi membangkitkan keampuhan dan kesaktian.

Sebagaimana yang terjadi, kebatinan juga menunjukkan ciri pembawaan penting dari filosofi hidup kejawen dan pembentukan kebudayaannya. Praktik religius dan kebatinan yang mistik adalah bagian dari kejawen, dan meskipun unsur-unsur religius tidak sepenuhnya dominan, tapi tidak juga sepenuhnya dapat dihilangkan dari gaya konseptualisasi yang menekankan pada keutuhan dan kesatuan hidup.......

Laku-laku semacam ini bertujuan untuk memperkuat batin (watak) dan meneyempurnakan rasa (intuisi) yang keduannya merupakan sifat peribadi yang menekankan individualitas dan subjektifisme, dan yang menunjukkan kebenaran dari pengalaman pribadi dan perasaan seseorang sebagai ukuran tinggi dari kebenaran. Ciri pembawaan subjektif yang berdiri berhadapan dengan kebutuhan akan disiplin sosial-tekanan untuk menyesuaikan dengan masyarakat dan harapan pemerintah memang cukup besar-membangkitkan keengganan umum terhadap dogma agama, dan kepuasan akan misteri dan hubungan-hubungan esoterik. Hal-hal yang jelas dan sederhana tidaklah begitu menarik; perjalanan pengembaraan mistik akan lebih menghibur ${ }^{8}$."

Sedangkan dalam tradisi pesantren legitimasi yang dikembangkan adalah semua dalam rangka keakhiratan. Baik air doa maupun amalan tidak ada yang yang bersumber, berpengamalan dan diperuntukkan pada hal-hal yang bertentangan dengan syariat islamatau jika mau disebut sebagai ajaran islam

${ }^{7}$ Niels Mulder, Ruang Batin Masyarakat Indonesia (Yogyakarta: LKIS, 2001), hal 120.

${ }^{8}$ Niels Mulder, Ruang Batin Masyarakat Indonesia (Yogyakarta: LKIS, 2001), hal 135. 
yang berlaku pada umumnya yang bersumber dari alquran dan hadits. Kita akan mendapati konstruksi sosial yang berbeda.

Kenyataan lain adalah, sejak masuknya Islam ke Jawa, para kiai telah menikmati kedudukan sosial yang tinggi. Dibawah pemerintahan kolonial belanda, para Sultan Jawa lebih menaruh perhatiannya terutama kepada aspekaspek politik pada kesultanan dan dalam pengertiannya yang kongkrit membiarkan masalah-masalah Islam ditangani oleh para kiai. Dengan demikian berarti sultan telah memberikan kekuasan penuh kepada kiai untuk mengatur masyarakat berkaitan dengan hal-hal agama9. Kalau yang ini, bisa dimungkinkan ada upaya-upaya khusus kesultanan dalam membangun kekuatan-kekuatan steakholdernya dengan memanfaatkan kiai sebagai tokoh yang bisa dilegitimasi secara kuat dari agama. Maka dibuatlah tradisi-tradisi yang bisa meneguhkan posisi kiai yang berarti juga meneguhkan posisi kesultanan. Bisa juga posisi yang diberikan oleh sultan dimanfaatkan oleh kiai untuk memperkuat dakwahnya dengan menciptakan tradisi-tradisi yang sekiranya bisa berpusat pada kiai. Jika demikian adanya maka hal ini masuk dalam "rekayasa sosial" tahap legitimasi dalam teori Berger. Kemungkinankemungkinan ini akan mendapat jawabannya nanti melalui penelusuran dengan mengacu pada pandangan masyarakat maupun kiai.

Bisa juga keberadaan tradisi-tradisi itu sebagai bentuk upaya perlawanan terhadap Belanda yang lebih mengusung semangat materialismenya. Sebagaimana dituliskan Ester Walcoot:

"Kepercayaan mistik bisa diketahui sejak abad XII pada waktu Agama Hindu dan Agama Budha paling berpengaruh. Kepercayaan mistik masih hidup selama proses islamisasi pada akhir abad XIII tetapi bentuknya berubah untuk menyesuaikan dengan agama yang baru. Pada akhir abad XIX kepercayaan ini mulai dilakukan dengan sengaja sebagai budaya Indonesia. Kecenderungan ini bisa dilihat sebagai jawaban terhadap penjajahan,yaitu ada kecenderungan untuk masyarakat tertentu untuk

${ }^{9}$ M. Hasyim Munif, Pondok Pesantren Berjuang (Surabaya: Sinar Wijaya, 1992), hal 8. 
memperkuatkan budaya pribumi atau menciptakan identitas yang melawan identitas penjajah ${ }^{10}$."

Berpijak pada permasalahan di atas, praktik ritual meminta air doa dan amalan pada kiai menjadi penting dikaji di samping sebagai bagian dari khazanah kekayaan tradisi Indonesia, juga sebagai kritik atas kajian terhadap kiai seperti yang dilakukan Geertz ${ }^{11}$, Binder ${ }^{12}$, Jay ${ }^{13}$, Noer $^{14}$, Steenbrink ${ }^{15}$, Taufik Abdullah ${ }^{16}$, Effendy ${ }^{17}$, Usman ${ }^{18}$ yang menunjukkan atas sisi pasif kiai dalam memoderasi budaya.Tulisan ini hendak mengungkap suatu hal yang berbeda dari peneliti tersebut. Melalui perspekth konstruksi sosial Berger, peneliti hendak menunjukkan identitas atupun peran yang dilakukan oleh kiai dalam ritual air doa dan amalanmerupakan bagian dari kepercayaan masyarakat yang menubuh dalam struktur sosial, di satu sisi, dan menjadi bagian dari misi kiai dalam menjaga spiritualitas umatnya, di sisi lain.

\section{METODE PENELITIAN}

Latar penelitian ini mengambil lokasi di daerah Jawa Timur. Praktik ritual air doa dan amalan yang menjadi kajian ini secara khusus meneliti pada Kiai Zuhri Zaini di Pesantren Nurul Jadid Paiton Probolinggo dan masyarakat yang tinggal di sekitar Pesantren Nurul Jadid Paiton Probolinggo. Saat ini Kiai Zuhri memimpin kurang lebih delapan ribu santri yang menetap di pesantren

\footnotetext{
${ }^{10}$ Ester Walcoot, Seni Pengobatan Alternatif Pengetahuan Dan Persepsi (Malang: Universitas Muhammadiyah Malang, 2004), hal 15.

${ }^{11}$ Clifford Geertz, 'The Javanese Kijaji : The Changing Role of a Cultural Broker', Comparative Studies in Society and History, 2.2 (1960), 228-49.

${ }^{12}$ Clifford Geertz, 'The Javanese Kijaji : The Changing Role of a Cultural Broker', Comparative Studies in Society and History, 2.2 (1960), 228-49.

${ }^{13}$ Leonard Binder, 'Islamic Tradition and Politics: The Kijaji and the Alim', Comparative Studies in Society and History, 2.2 (1960), 250-56. 1969).

${ }^{14}$ Robert R Jay, Javanese Villagers: Social Relations in Rural Modjokuto (Cambridge and London: MIT Press,

${ }^{15}$ Deliar Noer, The Modernists Muslim Movement in Indonesian 1900-1942 (London: Oxford University Press, 1973).

${ }^{16}$ Karel A Steenbrink, Pesantren, Madrasah, Sekolab: Pendidikan Islam Dalam Kurun Moderen (Jakarta: LP3ES, 1986).

${ }^{17}$ Taufik Abdullah, Agama Dan Perubahan Sosial (Jakarta: Rajawali, 1983).

${ }^{18}$ Bachtiar Effendy, 'Nilai-Nilai Kaum Santri', in Pergulatan Dunia Pesantren Membangun Dari Bawah, ed. by Dawam Raharjo (Jakarta: P3M, 1990).

At-Turäs: Jurnal Studi Keislaman

E-ISSN: 2460-1063, P-ISSN: 2355-567X

Volume 7, No. 1, Januari-Juni 2020
} 
dan total sebelas ribu dengan yang tidak menetap di pesantren. Untuk wilayah Probolinggo, Kiai Zuhri dengan Pesantren Nurul Jadidnya tercatat memiliki pengikut terbanyak dibandingkan dengan pesantren lainnya.

Untuk mengetahui konstruksi masyarakat terhadap air doa dan amalantersebut, penelitian ini menggunakan metode kualitatif. Peneliti memilih teknik sampling non probability dengan penentuan subjek secara purposive dan snow ball.Pengumpulan data dengan participant observationdan mewawancarai satukiai dan 8 masyarakat sekitar pesantren yang berkebutuhan khusus terhadap air doa dan amalan, seperti sakit, hamil, kesuksesan hidup dan lain sebagainya.

Dalam menganalisa data, kajian ini menggunakan pendekatan konsepsosiologi pengetahuanBerger. Analisa menekankan kepada konstruksi masyarakat dan kiai terhadap praktik ritual air doa dan amalan. Pada sudut pandang ini peneliti menggunakan tiga alat konstruksi Berger, yakni eksternalisasi, objektifasi dan internalisasi. Penggunaan pendekatan ini dapat melihat secara utuh dan mengungkap makna yang tersembunyi dalam hubungan realitas ganda pada praktik ritual air doa dan amalan ini.

\section{PEMBAHASAN}

\section{KIAI DALAM TRADISI AIR DOA DAN AMALAN}

Pelaksanaan ritual air doa dan amalan bagi masyarakat yang terpenting adalah kiainya. Status kiai dalam tradisi ini menempati upper class yang diyakini sebagai penjaga spiritualitas masyarakat. Dengan menggunakan konsep sosiologi pengetahuan Berger, setidaknya diketahui sejumlah faktor yang mempengaruhi posisi upper class kiai dalam tradisi ini, yakni nilai agama, spiritualitas pesantren dan mitos kiai.

Pertama, nilai agama. Ajaran Agama Islam sebagai fondasi dalam menjalankan praktik tradisi di pesantren. Pengaruh ajaran ini membentuk pula masyarakat yang ada di sekitar pesantren karena menjadi bagian yang tak 
terpisahkan dari pesantren dalam bertradisi. Begitupun dengan tradisi air doa dan amalan sebagai satu-kesatuan tradisi yang saat ini masih dijalankan dikalangan pesantren yang memiliki pengaruh kuat dari unsur keyakinan dalam agama.

Bagaimana tidak, di kalangan pesantren, tradisi ini selalu dihubungkan dengan kekuatan adi kodrati yang memiliki hak dalam menentukan terkabulnya hajat ketika berkebutuhan dengan air doa dan amalan. Sebagaimana Otto menjelaskan, bahwa setiap agama berpusat pada suatu konsep tentang hal yang ghaib (misterium) yang dianggap maha dahsyat (tremendum) dan keramat (sacrum) oleh manusia. Sifat dari hal yang ghoib dari suatu yang keramat adalah maha abadi, maha bijaksana,tidak terlihat, tidak batas dan sebagainya yang tidak bisa tercakup oleh pikiran manusia. Sifat-sifat hal yang ghoib tadi menimbulkan sikap kagum terpesona selalu akan menarik perhatian manusia dan mendorong timbulnya hasyat untuk menghayati rasa bersatu dengannya ${ }^{19}$.

Walaupun tradisi ini yang nampak adalah meminta air atau bacaan amalan pada seorang kiai, namun yang ada dalam keyakinan orang-orang dari kalangan pesantren itu hanyalah sebuah perantara. Sifat keperantaraan ini adalah doktrin agama yang tidak boleh menganggap ada kekuatan selain Dia Yang Maha Abadi. Sehingga tradisi ini mendapatkan legitimasinya dari agama sebagai hal yang sah-sah saja untuk dilaksanakan karena tetap berprinsip pada ajaran agama.

Dalam kaitannya dengan legitimasi keagamaan pula, Zuhri-sebagai kiai yang sering dimintai air doa dan amalan —-menyampaikan, bahwa amalantermasuk juga rukyah—sudah dilakukan oleh Nabi Muhammad SAW. dimasa hidupnya. Nabi sering memberikan bacaan-bacaan amalan misalkan untuk

${ }^{19}$ Sunyoto Usman, 'The Structural Interction of Elite Groups in Defelopment', Makalah Pada Forum Asean Muslim Social Scientist (Bandung, 1991). 
perlindungan, seperti misalnya sahabat saat itu dianjurkan untuk baca taawndz, atau membaca ayat kursi. Berikut pernyataan $\mathrm{Zuhri}^{20}$ :

"Jadi Nabi sendiri menganjurkan. Jadi berarti kan Nabi menawarkan amalan itu. $Y a$ ndak tau apa memang waktu itu apa ada sahabat yang meminta amalan, tapi yang jelas Nabi menganjurkan seperti itu. Dalam hadits juga banyak yang menerangkan, entah hadits itu shohih atau tidak, tapi kan dalam fadloilul a'mal kan boleh-boleh saja. Jadi misalnya, ada amalan untuk membaca surat waqiah supaya rizqinya lancar; Sholat dhuha misalkan dengan fadilah tidak akan kesulitan hidup, kemudian bisa juga menyehatkan dan seterusnya. Labini, memang ada hadits yang seperti itu."

Sehingga, bisa diyakinkan, tanpa ada unsur doktrin-doktrin agama, tradisi air doa dan amalan ini dikalangan orang pesantren tidak akan menemukan arus kuatnya. Karena itulah Berger menuliskan, bahwa agama sebagai suatu usaha manusia untuk membentuk suatu dunia kosmos keramat dalam suatu cara yang keramat (sakral), terhadap suatu kualitas kekuasaan misterius dan menakjubkan, bukan dari manusia tetapi berkaitan dengannya, yang diyakini berada dalam obyek-obyek pengalaman tertentu. Adanya keyakinan akan yang sakral atau keramat itulah tradisi ini bisa bertahan. Keramat itu, dikonstruksi oleh masyarakat sebagai akibat dari penyebaran budaya dan pencitraaan keagamaan manusia. Sehingga tidak menutup kemungkinan dalam tradisi ini adanya penggunaan unsur benda-benda adalah bagian dari pengaruh kebudayaan-kebudayan jawa, misalkan, yang bertemu dengan pencitraan keagamaan orang pesantren, sebagai perwujudan dalam mengaktualisasikan yang keramat. Karena aktualisasi, sebagaimana yang diungkapkan oleh Geertz ${ }^{21}$, menjadi penting dalam rangka membungkus konsepsi tentang tatanan-tatanan umum keagamaan agar bagi perasaan dan motivasi nampak realistis.

${ }^{20}$ Wawancara pada tanggal (20/12/2019)

${ }^{21}$ Brian Morris, Antropologi Agama (Yogyakarta: AK Group, 2003). 
Pencitraan keagamaan lainnya muncul dalam pemahaman ikhtiar (usaha) dalam memenuhi kebutuhannya. Sebagaimana yang diungkapkan oleh Zuhri, bahwa air doa dan amalan itu bagian dari ikhtiar yang diperintahkan oleh Allah. Ikhtiarnya yakni dengan mencari sebab-sebab yang telah ditetapkan oleh Allah. Allah itu menciptakan segala sesuatu dengan sabab (hal yang menjadi penyebab yang mengakibatkan munculnya hal yang lain), yang berwujud media-media tertentu yang telah ditetapkan oleh Tuhan sendiri. Berikut pernyataan dari Zuhri ${ }^{22}$ :

"Katakanlah misalkan, seperti menumbuhkan tumbuhan dengan sabab air, dan kesembuhan dengan sabab menggunakan obat. Lah itu kan hanya media saja sebetulnya. Hakikatnya yang menyembuhkan ya Allah."

Dalam hal soal menentukan sabab, lanjutnya, Allah menciptakan sabab tidak hanya satu pilihan, tapi sebaliknya dengan berbagai macam varian; ada yang biasa-biasa dan ada yang luar biasa; Ada yang konvensional dan non konvensional (modern). Sabab-sabab yang biasa adalah sabab yang dalam pandangan masyarakat sudah cukup lumrah, dalam artian tidak aneh karena jarangnya terjadi. Sebaliknya, sabab yang luar biasa adalah sabab-sabab yang jarang terjadi dalam pandangan masyarakat, sehingga terbilang aneh atau luar biasa.

Dilihat dari sudut pandang Berger dalam situasi tradisi ini, maka agama sebagai pranata sosial diciptakan untuk manusia dan agama juga mengembangkan realitas objektif lewat konstruksi sosial. Secara empirik, pranata-pranata itu selalu berubah seiring dengan perubahan kepentingan individu. Dalam konteks ini, agama memelihara realitas yang didefinisikan secara sosial dengan melegitimasi situasi-situasi marjinal dalam kerangka suatu realitas spiritual yang di dalamnya manusia eksis dalam kehidupan seharihari. Oleh karena itu, dalam konstruksi realitas secara sosial, agama

${ }^{22}$ Wawancara pada tanggal (20/12/2019) 
dapat dikatakan melayani dua tujuan penting, yaitu menyediakan makna dari realitas dan sekaligus melegitimasi realitas tersebut ${ }^{23}$.

Kedua, spiritualitas pesantren. Konsep tentang spiritualitas mengacu pada kepercayaan dan praktik yang didasarkan pada keyakinan bahwa ada dimensi nonfisik (transcendent) dalam kehidupan. Spiritualitas menggambarkan hubungan antara manusia dan tuhan dan berbagai kebajikan yang dihasilkan dari hubungan tersebut. Kebajikan tersebut diyakini secara nyata dalam mencapai prinsip dalam kehidupan dan kebaikan dalam kehidupan. Menjadi spiritual berarti mempunyai ikatan yang lebih terhadap wilayah kerohanian atau batiniah dibandingkan dengan wilayah fisik maupun materi. Bisa saja berhubungan dengan materi, namun hanyalah sebagai perantara untuk memenuhi tujuan kerohanian atau batiniahnya ${ }^{24}$.

Sangat penting dalam memahami tradisi air doa dan amalan melalui pendekatan dimensi spiritualitas pelakunya. Karena, sebagaimana telah terdefinisikan tentang spiritualitas, tradisi ini diyakini oleh kalangan pesantren didasarkan pada keyakinan ada dimensi nonfisik (transcendent) dalam kehidupan—tanpa melupakan dimensi fisik—untuk mencapai drajat kesalehan dalam setiap tindak-tanduk apapun.

Tradisi ini berbeda makna dengan tradisi jawa melalui praktik kebatinan dalam filosofi kejawennya. Sebagaimana dinyatakan Mulder, praktek kebatinan sama sekali tidak ditujukan untuk keakhiratan dan cenderung lebih pada menjauhi doktrin-doktrin agama.

Begitupun tidak sama pula dengan praktek keagamaan yang diungkapkan oleh Durkheim tentang dikotomi sakral dan profan ${ }^{25}$, karena dalam spiritualitas pesantren menekankan adanya kesatuan pandangan hidup

${ }^{23}$ Clifford Geertz, The Religion of Java (Illinois: Massachusetts Institute of Technology, 1960).

${ }^{24}$ Peter L. Berger, The Sacred Canopy: Element of a Sociological Theory of Religion (New York: Anchor Books, 1969).

${ }^{25}$ Seligman \& Peterson, 'Character Strengths and Virtues', in A Handbook and Classification (New York: Oxford University Press, 2004). 
antara duniawi dan ukhrowi, bahwa keduanya mengarah pada satu tujuan yakni Allah Yang Maha Esa.

Melihat sisi spiritualitas dalam tradisi air doa dan amalan, maka penulis menggunakan hasil dari penelitian Elkins ${ }^{26}$ berupa sembilan komponen spiritualitas, yakni: dimensi transenden, makna dan tujuan, misi, kesakralan hidup, nilai-nilai material, altruisme, idealisme, kesadaran akan peristiwa tragis dan buah dari spititual.

a. Dimensi transenden

Individu spiritual percaya akan adanya dimensi transenden dari kehidupan. Inti yang mendasar dari komponen ini bisa berupa kepercayaan terhadap tuhan atau apapun yang dipersepsikan oleh individu sebagai sosok transenden. Kepercayaan ini akan diiringi dengan rasa perlunya menyesuaikan diri dan menjaga hubungan dengan realitas transenden tersebut. Individu yang spiritual memiliki pengalaman bersentuhan dengan dimensi transenden.

Dalam tradisi air doa dan amalan ini dimensi transendennya terungkap dari term-term yang disampaikan oleh subyek penelitian dengan bahasa barokah dari Allah, nyambung kepada Allah, Allah dapat memenuhi hajat, bersandar kepada Allah, kekuatan Allah dalam menyelesaikan persoalan-persoalan, kedekatan kiai kepada Allah, wasilah kepada Allah, izin dari Allah, terbukti atau tidak bergantung kepada Allah, ikhtiar diperintahkan oleh Allah, hakikatnya kembali kepada Allah, mohon kepada Allah, media-media yang ditetapkan Allah, yang meneyembuhkan Allah, Allah yang menciptakan sebab, yang menentukan Allah, mohon pertolongan kepada Allah, ketentuan kembali kepada Allah, kiai menyampaikan barokah dari Allah, yang mengabulkan hanyalah Allah, memasrahkan kepada Allah dan hamba Allah yang kotor.

${ }^{26}$ Emile Durkheim, The Elementary Forms of the New Religious Life (London: Routledge, 1984). 
Dengan demikian dimensi transenden yang kuat adalah berhubungan dengan Allah sebagai pemilik kekuasaan. Sedangkan untuk menjaga hubugan dengan Allah, melalui kiai; melalui amalan-amalan yang diberikan oleh kiai. Karena kiai pewaris para nabi, dan nabi adalah kekasih Allah.

b. Makna dan tujuan dalam tradisi air doa dan amalan

Individu yang spiritual memahami proses pencarian akan makna dan tujuan hidup. Dari proses pencarian ini, individu mengembangkan pandangan bahwa hidup memiliki makna dan bahwa setiap eksistensi memiliki tujuannya masing-masing. Dasar dan inti dari komponen ini bervariasi namun memiliki kesamaan yaitu bahwa hidup memiliki makna yang dalam dan bahwa eksistensi individu di dunia memiliki tujuan.

Makna yang terbangun, sebagaimana diungkapkan Kiai Zuhriterhadap air doa maupun amalan ini hanyalah sebagai media, sebagai bentuk ikhtiar yang diperintahkan oleh Allah kepada manusia. Sehingga tetap hasil akhirnya kembali kepada Allah sebagai penentunya.

Makna terhadap penggunaan air yang banyak dijadikan media, pertama karena hal itu sudah tradisi dari sejak dulu. Kedua sesuai dengan penemuan-penemuan baru bahwa air itu bisa bereaksi ketika diberi ungkapan-ungkapan.

Kiai Zuhri memberikan makna mengenai banyaknya masyarakat yang meminta air doa dan amalan itu adalah wajar-wajar saja. Namun, lanjutnya, memang perlu diluruskan niat dan caranya; jangan sampai masyarakat itu bersandar dan memohon kepada makhluk termasuk orang yang dimintai itu, karena dihawatirkan jatuh dalam kekufuran.Sekaligus juga perlu diberi pemahaman bahwa sabab yang paling pokok dalam ajaran 
Islam adalah doa. Persoalan memilih sabab dengan media-media lainnya, itu hanyalah bagian dari pernik-pernik saja. Berikut Pernyataan Zuhri ${ }^{27}$ :

"Jadi ketika mereka datang (meminta amalan atau air doa), kalau memang kira-kira mereka awam, ya itu perlu diluruskan, bahwa sebetulnya yang menyembuhkan dan menentukan adalah Allah. Jadi, apapun dan siapapun itu hanyalah media yang dijadikan sabab oleh Allah, dan tentu sabab yang paling pokok dalam ajaran kita adalah doa; memohon pertolongan kepada Allah. Ya soal pakai media-media lain itu tambahan saja saya kira. Yang pokok itu doannya."

Mengenai makna perannya yang diposisikan oleh masyarakat sebagai orang yang dimintai air doa dan amalan, Kiai Zuhri berpendapat, bahwa ini adalah peranan dalam memberikan pelayanan kepada masyarakat karena masyarakat masih menganggap ini adalah kebutuhan. Selain itu, peranan ini juga bisa dijadikan sebagai media dakwah dalam memotivasi masyarakat untuk selalu rajin dan taat beribadah.

Dalam tradisi air doa dan amalan ini ada dorongan untuk menguatkan mental dan rohani. Karena hal itu bisa mempengaruhi terhadap daya tahan tubuh dalam menghadapi penyakit-penyakit, sehingga bisa lebih kuat dan lebih cepat sembuh.

Dasar atas perannya yang dilakukan ini, ia memaknai, bahwa amalan—termasuk juga rukyah—sudah dilakukan oleh Nabi Muhammad SAW. dimasa hidupnya. Nabi sering memberikan bacaan-bacaan amalan misalkan untuk perlindungan, seperti misalnya sahabat saat itu dianjurkan untuk baca taawudz atau membaca ayat kursi. Berikut pernyataannya ${ }^{28}$ :

"Jadi Nabi sendiri menganjurkan. Jadi berarti kan Nabi menawarkan amalan itu. Ya ndak tau apa memang waktu itu apa ada sahabat yang meminta amalan, tapi yang jelas Nabi menganjurkan seperti itu. Dalam hadits juga banyak yang menerangkan, entah hadits itu shohih atau tidak, tapi kan dalam fadloilul a'mal kan boleh-boleh saja. Jadi misalnya, ada amalan untuk membaca surat waqiah supaya rizqinya lancar; Sholat dhuha misalkan dengan fadilah tidak akan kesulitan hidup, kemudian bisa juga

${ }^{27}$ Wawancara pada tanggal $(20 / 12 / 2019)$

${ }^{28}$ Wawancara pada tanggal $(20 / 12 / 2019)$ 
menyehatkan dan seterusnya. Labini, memang ada hadits yang seperti itu."

Begitupun dengan banyaknya hadits yang memberikan keterangan tentang fadloilul a'mal (keutamaan-keutamaan amalan-amalan ibadah)— terlepas dari hadits shoheh atau tidak-lanjut beliau menerangkan, bahwa sebenarnya hadits-hadits itu menunjukkan bahwa doa dan amalan-amalan itu tidak hanya melulu untuk tujuan-tujuan akhirat tapi juga untuk urusan urusan duniawi. Hal itu beliau nyatakan memang ada dan memang diajarkan oleh Nabi, kemudian diteruskan oleh para ulama. Berikut pernyataanya ${ }^{29}$ :

"Bahkan suatu ketika ada beberapa orang sahabat yang mereka itu bepergian, kemudian ditengah jalan mereka kelaparan, akhirnya minta makan disuatu kampung, tapi oleh penduduk kampung itu tidak diberi. Kebetulan waktu itu kepala kampungnya disengat kalajengking, singkat cerita sudah diobati tapi tidak sembuh-sembuh. Kemudian ada yang mengusulkan: barangkali orang-orang tadi yang lewat itu bisa menyembuhkan. Akhirnya, oleh sahabat tadi diobatilah dengan bacaan fatihah, kemudian kepala kampung itu sembuh. Akhirnya oleh kepala kampung tadi, sahabat yang menyembuhkan diberi kambing. Hanya saja sahabat waktu itu ragu ketika diberi kambing; kira kira ini halal atau tidak. Karena sahabat kan belum tahu ya hukumnya. Akhirnya kambing itu dibawa kepada Nabi dan diceritakanlah oleh sahabat itu kejadian tadi kepada Nabi. Sabda Nabi: "loh, kamu kok tau kalau fatehah itu bisa jadi obat..... Kalau begitu saya minta bagian kambingnya..." jika melihat pada hadits ini berarti kan halal-halal saja kita melakukannya."

Makna meminta air doa atau amalan yang ditujukan pada Kiai, dalam pandangan Kiai Zuhri, ini terletak pada keyakinan orang yang meminta. Kalau yang meminta itu yakin, pada kiai siapapun insyaallah itu bermanfaat. Sebaliknya, kalau tidak yakin, siapapun tidak akan bermanfaat. Hal ini beliau nyatakan sesuai dengan hadits qudsi:ana inda dronni abdibi (Aku—Allah—bergantung kepada bagaimana hambaku mempersangkakan Aku). Dalam persoalan ini termasuk juga husnudzon pada seseorang. Dari

${ }^{29}$ Wawancara pada tanggal (20/12/2019) 
busnudzon itulah nanti akan melahirkan sugesti yang mendorong orang tersebut untuk yakin terhadap apa yang dia lakukan. Sehingga, kalau orang tersebut tidak yakin, maka tidak akan tersugesti.

Selain itu ada makna-makna khusus yang dipesankan, bahwa alangkah baiknya jika meminta air doa atau amalan itu pada orang yang ngerti syariah, biar tidak salah jalan.

Beliau juga memaknai terkait dengan orang yang dimintai memberikan air doa dan amalan bisa juga memiliki niat yang bermacammacam, sehingga dijadikan media untuk tujuan yang bermacam-macam pula; seperti cari uang, untuk tujuan politik ataupun dakwah. Sama dengan orang baca quran, baca sholawat bisa untuk tujuan yang bermacam-macam.

Dalam kenyataannya, fakta meminta air doa dan amalan ini tetap bertahan, makna yang beliau sampaikan adalah, karena manusia dalam kehidupannya suatu ketika pasti akan mengalami jalan buntu. Ketika itu terjadi, akhirnya manusia mencari alternatif-alternatif yang bermacammacam; ada yang ke kiai, ada yang ke dukun. Bahkan ada yang bunuh diri. Sebetulnya mereka ingin lari kepada Tuhan, tapi ada yang tidak tahu caranya. Berikut penjelasan Zuhri ${ }^{30}$ :

"Jadi, manusia itu pada dasarnya kan makhluk yang bertuhan. Ketika mereka itu mengalami jalan buntu atau mentok, ya kemudian ingin mencari gantungan atau sandaran, ya macem-macem caranya. Tapi kalau orang yang bisa nyambung kepada Tuhan ya langsung, tapi kalau orang yang tidak nyambung bisa cari media yang bermacam-macam itu."

Tentang makna kemasukakalan meminta air doa dan amalan, beliau menyatakan, kalau kita menggunakan logika agama, fakta ini tergolong masuk akal. Dalam ranah tauhid ini halmasuk akal. Tapi kalau logika medis yang tidak disambung dengan ilmu-ilmu agama, mungkin tidak masuk akal. Tapi, sekarang inisudah banyak orang yang memadukan pendekatan medis dan non medis; pendekatan batiniah-rohaniah dengan pendekatan fisik-

${ }^{30}$ Wawancara pada tanggal (20/12/2019) 
jasmaniah. Nyatanya memang bermacam-macam penilaian-baik yang datang dari diri sendiri maupun orang lain-terhadap usaha seseorang untuk mencapai cita-cita hidupnya. Ada yang dianggap logis-wajar, tapi menurut orang lain tidak dianggap logis dan wajar. Tentunya masingmasing punya logika sendiri-sendiri. Berikut penjelasan Zuhri ${ }^{31}$ :

"Nah, dalam hal ini (air doa dan amalan) hasilnya kan masih bisa dibuktikan. Seperti pengobatan alternatif; baik melalui herbal dan ada juga yang doa-doa, itu tetap jalan dan laku, berati kan memang ada hasilnya. Entah prosesnya bagaimana ya kita tidak tau, tapi bisa dilihat hasilnya, berarti kan efektif."

Akhirnya, inti dari tujuan peran yang dilakukan kiai dalam memberikan air doa dan amalan ini adalah memberikan pelayanan dan dakwah. Bagi beliau, pelayanan dan dakwah kepada masyarakat harus tetap jalan walaupun tidak harus menggunakan media air doa dan amalan-jika tidak ada lagi yang menghendaki. Berikut petikan penjelasan Zuhri ${ }^{32}$ :

"Jadi bukan harus dipertahankan. Jadi kita kan ingin melayani, menolong orang dan sekaligus juga berdakwah. Artinya kalau memang sudah tidak ada lagi yang percaya ya kita tidak perlu promosi untuk menyampaikan kepada masyarakat. Kalau dakwah kan memang harus terus jalan, tapi medianya kan tidak hanya itu."

c. Misi tradisi air doa dan amalan

Individu merasakan adanya panggilan yang harus dipenuhi, rasa tanggung jawab pada kehidupan secara umum. Pada beberapa orang bahkan mungkin merasa akan adanya takdir yang harus dipenuhi. Pada komponen makna dan tujuan tradisi ini, individu mengembangkan pandangan akan hidup yang didasari akan pemahaman adanya proses pencarian makna dan tujuan. Sementara dalam komponen misi tradisi ini, individu memiliki metamotivasi yang berarti mereka dapat memecah

${ }^{31}$ Wawancara pada tanggal (20/12/2019)

${ }^{32}$ Wawancara pada tanggal $(20 / 12 / 2019)$ 
misinya dalam target-target konkrit dan tergerak untuk memenuhi misi tersebut.

Bagi kiai, misi yang menggerakkan adalah ikhtiar untuk memenuhi perintah Allah, ibadah; mendekatkan diri kepada Allah, pelayanan kepada masyarakat, dakwah li i'la kalimatillah. Sedang bagi masyarakat, tradisi ini membawa misi ikhtiar dan beribadah untuk mendekatkan diri kepada Allah.

d. Kesakralan tradisi air doa dan amalan

Individu yang spiritual mempunyai kemampuan untuk melihat kesakralan dalam semua hal hidup. Pandangan akan hidup mereka tidak lagi dikotomi seperti pemisahan antara yang sakral dan yang sekuler, atau yang suci dan yang duniawi, namun justru percaya bahwa semua aspek kehidupan suci sifatnya dan bahwa yang sakral dapat juga ditemui dalam hal-hal keduniaan.

Kesakralan utama dalam tradisi ini adalah Allah sebagai kekuatan penentu. Sedangkan lainnya adalah disakralkan karena mendapat dukungan dari kesakralan utama. Yang kedua ini adalah bentuk dari "derivasi kesakralan" dimana kesakralan yang diyakini adalah temporal dan bergantung kepada atsar (faktor-faktor lain), sehingga masih ada muncul "label wasilah atau perantara".

Kiai disakralkan pertama karena mendapat label sebagai wasilah kepada Allah. Sebutan ini sebagai bentuk manifestasi dari dogma yang berkembang bahwa kiai atau ulama adalah pewaris para nabi dan nabi adalah kekasih Allah. Kedua ditambah dengan penguatan pensakralan dari masyarakat karena memandang kiai sebagai pribadi yang menurut cadangan pengetahuan masyarakat adalah pribadi yang baik. Ketiga, adanya kharisma pada kiai yang diseebabkan dari faktor keturunan, kedudukan atau keahlian. 
Hal lain yang mendapat "derivasi kesakralan" adalah air doa atau amalan yang diminta kepada kiai. Air doa atau amalan ini diyakini kesakralannya sebagai perantara untuk memohon kepada Allah yang dapat mengabulkan hajat. Kesakralanya diperoleh dari kiai yang memberikan air doa atau amalan yang sebagiannya diambilkan oleh kiai dari teks-teks ajaran agama.

e. Nilai-nilai material tradisi air doa dan amalan

Individu yang spiritual menyadari akan banyaknya sumber kebahagiaan manusia, termasuk pula kebahagiaan yang bersumber dari perolehan bagian keduniawian. Oleh karena itu, individu yang spiritual menghargai perolehan keduniawian namun tidak mencari kepuasaan sejati dari hal-hal tersebut. Mereka menyadari bahwa kepuasaan dalam hidup semestinya datang bukan dari seberapa banyak perolehan keduniawian yang dimiliki.

Dalam tradisi ini, oleh masyarakat difahami hal-hal yang menjadi hajat keduniawian bukanlah tujuan utama. Namun hajat keduniawian itu tidak juga dipungkiri sama sekali. Artinya, berharap terkabul, iya, tapi semua dikembalikan kepada Allah sebagaimana tujuan hidupnya.

Ketika hajat keduniawian itu terkabul, maka penghargaan terhadapnya juga bagian yang penting sebagai wujud syukur kepada Allah. Penghargaan yang dimaksudkan adalah menggunakan sebagaimana tuntutan dari Yang Maha Mengabulkan. Sehingga, nilai dari perantara seperti air doa dan amalan sama halnya dengan nilai hajat keduniawian.

f. Altruisme tradisi air doa dan amalan

Individu yang spiritual menyadari akan adanya tanggung jawab bersama dari masing-masing orang untuk saling menjaga sesamanya (our brother's keepers). Mereka meyakini bahwa tidak ada manusia yang dapat berdiri sendiri, bahwa umat manusia terikat satu sama lain sehingga 
bertanggung jawab atas sesamanya. Keyakinan ini sering dipicu oleh kesadaran mereka akan penderitaan orang lain. Nilai humanisme ini diikuti oleh adanya komitmen untuk melakukan tindakan nyata sebagai perwujudan cinta altruistiknya pada sesama.

Maka seorang kiai memiliki prinsip dalam tradisi ini sebagai bentuk pelayanan kepada masyarakat tanpa mengharakan imbalan apapun. Bagi masyarakat sendiri, terutama yang mendapatkan bukti keberhasilan dari tradisi ini, ikut membantu berusahanya teman, saudara atau orang lain sama dengan yang dilakukannya. Bahkan dengan mengantarnya kepada kiai.lebih dari itu, mewakili orang yang berhajat untuk ke kiai.

Selain itu, nyatanya sifat-sifat kiai yang berkaitan dengan hubungan baik kemanusiaan dan kemasyarakatan dijadikan pertimbangan ketika meminta air dan amalan. Disadari atau tidak, yang mempertimbangkan akan meniru yang dipertimbangkan. Lebih-lebih jika hajatnya terpenuhi.

g. Idealisme tradisi air doa dan amalan

Individu yang spiritual memiliki kepercayaan kuat pada potensi baik manusia yang dapat diaktualisasikan dalam berbagai aspek kehidupan. Memiliki keyakinan bukan saja pada apa yang terlihat sekarang namun juga pada hal baik yang dimungkinkan dari hal itu, pada kondisi ideal yang mungkin dicapai. Mereka percaya bahwa kondisi ideal adalah sesuatu yang sebenarnya mungkin untuk diwujudkan. Kepercayaan ini membuat mereka memiliki komitmen untuk menjadikan dunia tempat yang lebih baik, setidaknya dalam kapasitasnya masing-masing. Dengan bahasa lain, hidup ini bukan hanya saat ini dan sekarang, tapi ada masa depan.

Dalam tradisi ini ada idealisme yang dinyatakan oleh masyarakat. Idealisme itu berupa:

1. Mengidealkan keseimbangan fisik-jasmaniah dengan batiniah-rohaniah 
2. Mengidealkan kuatnya mental dan rohani, karena menjadi sumber kekuatan utama bagi kekuatan fisik.

3. Mengidealkan bablun minaallah dan hablun minannas (hubungan baik kepada Allah dan kepada makhluknya)

4. Salah satu solusi dalam pemecahan persoalan secara spiritual dan menuntun jalan mengembalikan semuanya kepada Allah

h. Kesadaran akan peristiwa tragis

Individu yang spiritual menyadari akan perlu terjadinya tragedi dalam hidup seperti rasa sakit, penderitaan atau kematian. Tragedi dirasa perlu terjadi agar mereka dapat lebih menghargai hidup itu sendiri dan juga dalam rangka meninjau kembali arah hidup yang ingin dituju. Peristiwa tragis dalam hidup diyakininya sebagai alat yang akan membuat mereka semakin memiliki kesadaran akan eksistensinya dalam hidup.

Kesadaran-kesadaran yang muncul ketika bersentuhan dengan tradisi ini adalah:

1. Masalah yang muncul disadari sebagai bentuk ujian

2. Amalan-amalan yang diberikan diyakini dapat melebur dosa-dosa

3. Penyakit dan kesulitan-kesulitan lainnya adalah jalan yang disediakan oleh Allah untuk kembali kepadaNya.

4. Dengan adanya masalah; baik yang dialami sendiri maupun orang lain, dapat menjadi alasan lebih dekat dengan kiai.

5. Menarik empati dan simpati seseorang terhadap orang lain yang kesulitan

6. Semua itu adalah wejangan dan teladan yang muncul dari kiai.

i. Buah dari spiritualitas

Komponen terakhir merupakan cerminan atas kedelapan komponen sebelumnya dimana individu mengolah manfaat yang dia peroleh dari pandangan, kepercayaan dan nilai-nilai yang dianutnya. Pada komponen ini 
individu menilai efek dari spiritualitasnya, dan biasanya dikaitkan dengan hubungannya terhadap diri sendiri, orang lain, alam, kehidupan, dan apapun yang dipersepsikannya sebagai aspek transenden.

Dalam tradisi ini buah dari spiritual yang dirasakan adalah:

1. Dekat dengan ulama

2. Ketenangan setelah menghadap pada kiai dan memperoleh air doa atau amalan dari kiai.

3. Kepuasan bertemu dengan kiai dan mendapat wejangan-wejangan dari kiai.

4. Khouf (takut) karena banyak dosa.

5. Roja (harapan) Allah mengabulkan

6. Ikhtiar yang diliputi pasrah/tawakal dengan segala keputusanNya

7. Bergantung kepada AllahAnugerah istiqomah

Ketiga, mitos kiai. Sampai saat ini masyarakat yang mendapat pengaruh dari pesantren, khususnya mereka yang pernah berguru pada kiai di pesantren, cenderung menjadikan kiai sebagai sosok central dalam perihal kehidupannya. Pendapat Mulder ${ }^{33}$, bahwa masyarakat mengkultuskan kiai dengan menjadikannya sebagai pepundhen menampak pula pada kehidupan masyarakat di sekitar Pesantren Nurul Jadid. Segala persoalan mulai dari kelahiran sampai kematian, diapresiasi oleh masyarakat sebagai alur kehidupan yang membutuhkan campur tangan sosok kiai di dalamnya. Kepercayaan ini tersimbolisasi dalam keyakinan bahwa "kiai adalah pewaris para nabi". Simbolisasi yang mendapatkan legitimasi agama ini menjadi menjadi kepercayaan atau bahkan mitos yang kuat bahwa kiai adalah orang yang paling tidak diberi mandat untuk menyampaikan kearifan para nabi, sebagaimana

${ }^{33}$ David N. Elkins, 'Toward a Humanistic-Phenomenological Spirituality Definition, Description, and Measurement', Journal of Humanistic Psychology, 28.4 (1998), 5-18. 
yang diyakini Ponirin ${ }^{34}$. Bahkan kepercayaan itu tetap melekat sampai ketika orang yang dikultuskan sebagai kiai itu meninggal dunia.

Selain pengaruh dari doktrin agama, pengkultusan kepada kiai juga dipengaruhi oleh budaya yang berkembang berupa "nderek kiai" dan "jejer pandhita". ${ }^{35} \mathrm{Hal}$ ini di lingkungan Pesantren Nurul Jadid hal ini masih sangat kental. Sebagaimana disebutkan dalam tulisan sebelumnya, masyarakat sangat kuat kebergantungannya kepada kiai dalam segala hal urusan baik yang berkaitan dengan keakhiratan maupun urusan keduniawian. Masyarakat masih percaya bahwa kiai adalah orang yang diberi kekuatan khusus oleh Allah dengan kemampuan banyak hal. Kemampuan inti itu berupa doa mujarab karena kiai diyakini sebagai orang yang dekat dengan Allah.

Bukan hanya hal keakhiratan dan keduniawian saja yang diyakini masyarakat bisa diselesaikan dengan perantara kiai, juga hal-hal yang berkaitan dengan kehidupan di alam ghaib. Kiai diyakini bisa melakukan komunikasi dengan kehidupan alam ghaib, karena pada masyarakat masih berkembang kepercayaan tentang adanya makhluk-makhluk dari alam ghaib; baik yang bisa memberikan kekuatan maupun yang dianggap menjadi gangguan. Sebagaimana yang diungkapkan oleh Firma ${ }^{36}$ :

"saya yakin beliau (Kiai Zuhri) bisa mengkomunikasikan dengan arwah Kiai Abdul Haq yang sudah meninggal."

Kepercayan lainya adalah sebagaimana yang di ungkapkan oleh Riklefsyang telah melakukan berbagai penelitan di pesantren jawa, yakni tentang keyakinan masyarakat terhadap kekeramatan kiai, ${ }^{37}$ keyakinan masyarakat di lingkungan Pesantren Nurul Jadid terhadap kiai diasosiasikan memiliki kekuatan adimanusiawi, menguasai beragam ilmu keislaman tanpa

\footnotetext{
${ }^{34}$ Wawancara pada tanggal $(10 / 12 / 2019)$

${ }^{35}$ Ahmad Baso, Pesantren Studies Buku II (2a) : Kosmopolitanisme Peradaban Kaum Santri Di Masa Kolonial (Jakarta: Pustaka Afid, 2012).

${ }^{36}$ Wawancara pada tanggal $(06 / 12 / 2019)$

${ }^{37}$ Ahmad Baso, Pesantren Studies Buku II (2a) : Kosmopolitanisme Peradaban Kaum Santri Di Masa Kolonial (Jakarta: Pustaka Afid, 2012).
} 
perlu mempelajarinya, memiliki anugerah untuk meramalkan sesuatu, bisa menyembuhkan sakit dan memeberikan kekebalan. Hal yang senada juga terjadi pada penelitian Dhofirtentang kepercayaan masyarakat terhadap kemampuan-kemampuan adimanusiawi kiai yang menjadikan kiai sebagai sosok yang keramat. ${ }^{38}$

Berikut ini adalah klasifikasi hasil temuan pada masyarakat di sekitar Pesantren Nurul Jadid terhadap kiai terkait dengan kepercayaan dan pola pikir yang memposisikan kiai sebagai sosok yang keramat. Kepercayaan dan pola pikir itu dikaitkan dengan permintaan mereka kepada kiai agar memberikan air doa dan amalan.

\section{Tabel 1.1: Alasan Kiai Dikeramatkan}

\section{Alasan Kiai Dikeramatkan}

- Kiai adalah pewaris para nabi

- Kiai Diberi barokah oleh Allah

- Kiai Diberi perantara oleh Allah untuk menyampaikan barokah kepada hambaNya,

- Kiai dekat kepada Allah; karena memiliki sifat-sitat yang disenangi Allah, seperti kepentingan orang lain yang didahulukan cara hidup zuhudnya (hidup sederhana),tawadlu, istiqomah, alim, sederhana, sabar, santun, penyayang, telaten, mengayomi santrinya, tidak suka melaknat santrinya apalagi masyarakat kalau berbuat salah kepada aturan lebih-lebih berbuat salah kepada kiai. hubungan dengan masyarakat juga sangat baik.

- Doanya kiai mujarab sekali.

- Kiai Mempunyai legalitas keagamaan dalam tindakannya

- Kiai Bisa berkomunikasi dengan alam ghaib.

Tabel 1.2: Pola Pikir Yang Mengkeramatkan Kiai Pola Pikir Yang Mengkeramatkan Kiai

- Sambung dengan orang yang sambung kepada Allah itu sudah sangat membanggakan.

${ }^{38}$ Dhofier, (1984). Tradisi Pesantren: Studi tentang Pandangan Hidup Kyai. Jakarta: LP3ES. 
- Hal terpenting dalam meminta air doa atau amalan kepada kiai adalah sambungannya kepada kiai.

- Merasa terlalu banyak dosa sehingga membutuhkan sambungan pada kiai,

- Meminta air doa atau amalan itu hanya terhadap kiai-kiai tertentu saja,

- Minta air doa atau amalan itu bukan karena air nya tapi karena kiainya,

- Percaya air doa kalau melihat kiai sendiri yang mendoakan langsung,

- Tidak sepenuhnya meyakini kepada air atau amalan yang diberikan, tapi lebih kepada siapa yang memberikan, karena air itu, tidak lebih layaknya air yang lain atau tulisan amalan itu begitu serupanya dengan tulisan yang lain. Tapi, ketika itu diberikan oleh seseorang yang luar biasa, jadilah benda-benda itu ikut menjadi luar biasa.

- Amalan itu diberikan oleh orang yang luar biasa, maka yang mengamalkan bisa juga berharap menjadi luar biasa

- Harapkan meleset yang diyakini bukan karena doanya kiai yang tidak mandhi (mujarab), tapi bisa jadi waktu mengamalkanya itu kurang mantab, atau masih banyak dosa yang harus dilebur dengan doa-doa itu.

- Meminta air doa dan amalan itu bukanlah tujuan. Bertemu dengan kiai saja itu sudah membuat tenang. Bisa melaksanakan amalan yang diberikan oleh kiai dengan istiqomah, sudah merupakan keberuntungan.

\section{SOSIALISASI PATRONASE PADA KIAI; ANTARA SIMETRIS DAN ASIMETRIS}

Mekanisme sosialisasi baik secara primer maupun secara skunder merupakan proses dari internalisasi dalam konsep Berger ${ }^{39}$. Dalam hal ini Berger mengikuti teori Mead dari aliran Interaksionisme Simbolik. Mekanisme sosiaalisasi ini merupakan konsekuensi dari kenyataan bahwa setiap orang akan dilahirkan ke dalam struktur sosial objektif dan dunia sosial objektif. Sehingga, pemahaman seorang akan sangat dipengaruhi oleh pemegang

\footnotetext{
${ }^{39}$ Thomas Berger,Peter L and Luckmann, The Sosial Construction of Reality: A Treatise in the Sociology of Knowledge (New York: Anchor Books, 1967).
} 
sosialisasi; yang menyampaikan bahan internalisasi berdasarkan pengalaman struktur sosialnya dan biografi-wataknya. Perlakuan orang-orang yang berpengaruh akan menciptakan generalisasi-subjektif pada anak. Dalam proses ini, individu akan selalu mengalami dialektika identitas yang diberikan orang lain (realitas objektif) dan identitas dari diri sendiri (realitas subjektif). Dengan demikian, proses ini dapat menjadikan identitas tertentu yang dihasilkan dari interaksi dengan orang-orang yang berpengaruh (tertentu pula) menghasilkan identitas seseorang yang secara umum diberlakukan dalam keadaan apapun. Selanjutnya, apabila dalam proses ini orang lain telah terwujud dalam kesadaran seseorang, maka terciptalah hubungan simetris kenyataan subjektif dan objektif. Namun, hubungan tersebut tidak akan selalu koekstensif; selalu akan lebih banyak ketersediaan kenyataan objektif daripada apa yang diinternalisasi. Dalam penelitian ini pula terdapat hubungan yang asimetris dalam proses sosialisasi patronase kiai.

Peneliti melihat mekanisme sosialisasi patronase pada kiai setidaknya dilakukan pada lingkungan keluarga, masyarakat dan pesantren. Pertama, lingkungan keluarga. Setiap orang akan dilahirkan ke dalam struktur sosial yang objektif dan dunia yang objektif. Keluarga menjadi pemegang kuasa pertama kali dalam dunia objektif atas pengasuhan anak yang dilahirkan untuk melakukan sosialisasi primer. Dari seluruh subyek penelitian menyatakan bahwa mereka dilahirkan pada lingkungan yang sangat memegang tradisi yang berkaitan dengan etika, moral, falsafah, dan kebatinan dalam masyarakat JawaMadura. Salah satunya adalah idiom atau unen-unen: bepak, bebuk, guru, ratoh. Ungkapan ini menyatakan tentang pentingnya menghormat pada bapak-ibu, guru dan pemerintah. Walaupun tidak selalu diungkapkan, kenyataannya selalu mewujud pada simbolisasi dalam prilaku yang terus diajarkan oleh orang tua maupun masyarakat sekitar. Simbolisasi itu diantaranya berupa mencium tangan ketika hendak bepergian maupun ketika datang; terutama kepada 
bapak-ibu dan guru, mengunjungi bapak-ibu dan guru dalam perayaanperayaan tertentu; seperti pada saat lebaran dan perayaan Maulid Nabi Muhammad, menyapa dan mennghormati kepada yang lebih tua ketika bertemu.

Sebagaimana diungkapkan Ghofur dan Bambang tentang ritual khusus yang beberapa kali dia lakukan kepada orang tua dengan menyiramkan air kepada telapak kaki ibunya untuk kemudian diminum. Berikut pernyataan Bambang $^{40}$ :

"saya melakukan itu karena memang saya yakin bahwa air basuhan kaki ibu itu bisa memberikan lantaran kesuksesan. Pernah suatu saat ketika saya merasa sumpek dan sulit mendapat pekerjaan maka itu (meminum air basuhan kaki ibu) saya lakukan. Dulu ketika saya waktu kecil juga pernah diberi air itu (basuhan kaki ibu) karena saya dianggap anak yang meler dan susah diatur."

Lain lagi dengan pengalaman yang dituturkan Ponirin. Menurut cerita dari orang tunya, sewaktu ia baru lahir, orang tuanya meminta bekas mamahan kurma kepada kiai untuk kemudian di cetakkan pada langit-langit mulutnya. Hal itu dilakukan dikenal dengan tafa'ulan atau berharap agar anak tersebut dapat seperti kiai yang dimintai mamahan kurma.

Tradisi lain diungkap oleh Suher dan Fadol bahwa ketika dulu pertama kali akan berangkat mondok, orangtuanya mengantarkan berpamitan kepada guru-guru terdekatnya terutama guru ngaji di langgar dan kepada saudara dan tetangga-tetangganya. Begitu juga nanti ketika datang dari pondok.

Bentuk-bentuk penjagaan tradisi yang diwariskan atau diajarkan oleh orang tua diakui oleh mereka cukup membekas menjadi sebuah kebiasaan yang tertanam kuat sampai sekarang dalam penghormatan kepada orang tua dan guru.

${ }^{40}$ Wawancara pada tanggal $(10 / 12 / 2019)$ 
Kedua, lingkungan masyarakat. Tahap berikutnya sosialisai dilakukan dilingkungan masyarakat—terutama oleh guru ngaji—yang tidak jauh berbeda dari sosialisasi yang dilakukan oleh orang tua mereka. Perbedaan hanya pada tingkat intensitas keyakinan kepada guru/kiai tertentu. Berikut pernyataan Suher ${ }^{41}$ :

"Dimasyarakat itu yang berkembang kalau soal berguru adalah kavlingkavling. Yang ini menyatakan berguru kesana saja. Yang satunya menyatakan berguru ke kiai itu saja. Tapi intinya dimasyarakat saya penghormatan pada kiai itu kuat."

Penghormatan itu diceritakan oleh Suher dalam bentuk antusiasme masyarakat untuk meminta campur tangan kiai dalam segala kubutuhan dan tahapan kehidupan mereka. Mulai dari pernikahan mengundang kiai, kehamilan empat bulan dan tujuh bulan minta doa dan mengundang kiai, melahirkan meminta doa kiai, selapan mengundang kiai, tujuh bulan anak mengundang kiai, kesuksesan anak minta doa kiai, dan kebutuhan lain seperti keberhasilan sawah, kelancaran rizki, konsultasi jodoh, hari baik menikah;memulai usaha; membangun rumah; menempati rumah; bahkan sampai kepada posisi kamar dan posisi rumah, persoalan rumah tangga, persoalan perdagangan, persoalan batin dan lain sebagainya.

Namun dari pengakuan Suher hal itu belum membentuk konstruk dalam pikirannya bahwa kiai itu adalah orang yang hebat. Karena dia oleh orang tuanya tidak pernah dikenalkan pada kiai-kiai. Hanya ketika mondok saja dia dibawa ke kiai oleh orang tuanya. Berbeda dengan Fadol dan Bambang yang memang sejak awal oleh keluarganya sering dibawa mengunjungi kiaikiai. Begitupun hal itu tidak membuat serta merta terbentuk keyakinan bahwa kiai adalah sosok yang sakti dan luar biasa. Berikut pernyataan Fadol ${ }^{42}$ :

"yang saya tahu waktu belum mondok, kiai itu ya orang yang dihormati, dicium tangannya, saya harus sopan kalau dihadapan kiai, jangan lari-lari

${ }^{41}$ Wawancara pada tanggal (22/12/2019)

${ }^{42}$ Wawancara pada tanggal (13/12/2019) 
bahkan sering-sering memandang matanya. Saya lihat orang tua saya kalau bicara dengan kiai halus sekali, tidak seperti ketika berbicara dengan saya. Yang mereka bicarakan banyak hal. Kadang persoalan politik, bisnis, masyarakat dan hukum-hukum islam. Kadang juga meminta amalan-amalan."

Baik dari mereka yang biasa sejak kecil dikenalkan kepada kiai maupun tidak atau hanya mendengar dari masyarakat tentang orang-orang yang banyak mengunjungi kiai untuk berbagai kepentingan, hal ini menghasilkan kesimpulan yang sama bahwa belum ada konstruk yang luar biasa dalam keyakinan pada kiai. Semua pengalaman hanya melihat pada sisi penghormatan dan apresiasi kenyamanan hidup ketika melihat kiai.

Ketiga, lingkungan pesantren. Para subyek penelitian menyampaikan bahwa kepercayaan kepada kiai sebagai orang yang istimewa, dekat dengan Allah, diberi barokah dan kekeramatan yang lain sehingga menjadikan mereka orang yang begitu taat kepada kiai, menguat ketika berada di pesantren dan langsung melihat dan berkenalan dengan kesehariankiai.Salah satunya diungkapkan oleh Fadol ${ }^{43}$ :

"Sosoknya beliau (Kiai Zuhri) sehari harinya saya tahu itukan saya dekat, maksudnya, saya itu sering berada dilingkungan pesantren. Kalau kiai-kiai yang lain itu yak apa ya kurang manteb karena saya lebih mengenal beliau dari interaksi langsung maupun tidak langsung; dari cara bicaranya beliau, akhlaknya, kebiasaanya sehari-hari yang memunculkan decak kagum pada diri saya kepada beliau itu. Dan itu diperkuat oleh kebanyakan pengalam dari teman-teman saya, cerita-cerita teman alumni, santri sepuh, para santri yang dekat secara personal dengan beliau. Itulah yang membuat saya semakin mantap.

Hal yang memantabkan saya juga pelajaran dari pesantren. Ilmu yang saya dapatkan dari pesantren terkait ilmu agama dan aklak itu diamalkan oleh beliau dengan baik. Jadi itu menjadi keyakinan tersendiri untuk saya jadi kalau ada apa-apa saya minta amalan maupun minta doa melalui media air"

Senada dengan Fadol, semua subyek penelitian yang lain menyatakan bahwa keberadaanya di pesantren dan pertemuan langsung dengan keseharian

${ }^{43}$ Wawancara pada tanggal (13/12/2019) 
kiai disamping membuat mereka sangat hormat pada kiai bahkan lebih selektif lagi dalam memilih kiai. Artinya, tidak semua kiai akan mereka posisikan sebagai sosok yang keramat. Ada kriteria khusus yang sebagaimana penulis klasifikasikan dalam sub bab kepercayaan (mitos) kekeramatan kiai. Melalui analisa diatas dapat dikatakan bahwa sosialisasi yang kuat terhadap pengkeramatan kiai adalah terjadi di pesantren dan melalui pengalaman pribadi.

Namun, tidak semua sosialisasi patronase terhadap kiai berjalan simetris. Ada hal-hal tertentu yang dikonstruksikan oleh masyarakat sehingga sosialisasi tentang peng-keramatan kiai tidak seutuhnya diterima (sosialisasi asimetris). Subjek penelitian memiliki logika tersendiri dalam merefleksikan sosialisasi yang telah terjadi dalam peng-keramatan terhadap kiai. Tidak semua kiai diasumsikan sebagaimana yang telah dipaparkan sebelumnya. Subjek penelitian disini cenderung mempunyai kerangka tersendiri dalam menentukan siapa kiai yang pantas untuk dikeramatkan dan siapa yang tidak. Salah satunya diungkapkan oleh Ponirin tentang hal-hal yang dapat membuatnya yakin dengan sosok kekeramatan kiai tertentu, berikut hasil wawancaranya ${ }^{44}$ :

"Kecondongan saya hanya pada kiai tertentu saja dengan melihat kriteriakriteria yang tertera dalam sumber kitab-kitab tasawuf. Menurut saya, banyak sekali dalam kitab tersebut diungkap sifat orang-orang yang dekat kepada Allah; seperti tawadlu, istiqomah, sederhana, sabar, telaten, mengayomi santrinya, dan tidak suka melaknat santrinya apalagi masyarakat kalau berbuat salah kepada aturan lebih-lebih berbuat salah kepada kiai itu"

Hal yang membuat subjek penelitian tidak serta-merta percaya pada kiai disebabkan oleh beberapa faktor yang berkaitan dengan perilaku hidup keseharian kiai, baik yang disaksikan secara langsung maupun berupa penilaian

${ }^{44}$ Wawancara pada tanggal (16/12/2019) 
yang berasal dari teman dan masyarakat. Dalam hal ini Fadol mengungkapkan ${ }^{45}$ :

"Saya paling tidak suka dengan kiai yang terlibat politik praktis. Karena seringkali kalau kiai itu berpolitik praktis, jamaahnya dibawa-bawa untuk mendukung pilihan politik kiai itu. Nah ini membuat tidak murni lagi niat kiai itu untuk membimbing masyarakat. Kalau sudah tidak murni lagi membimbing, ya buat apa diikuti. Karena, mesti banyak kepentingannya. Ujung-ujungnya jamaahnya diperalat untuk memenuhi nafsu kuasanya"

Selain yang diungkapkan oleh Fadol, subjek penelitian lainnya mengungkapkan alasan yang berbeda atas faktor yang menyebabkan sosialisasi yang mereka terima selama ini tentang peng-keramatan kiai tidak serta merta diterima. Firma memaparkan ketidak-percayaannya terhadap kiai yang terlibat bisnis praktis. Berikut pemaparannya ${ }^{46}$ :

"Kalau saya itu melihat kiai yang juga berbisnis kayak MLM, terus makelar tanah, bikin perumahan dan bisnis-bisnis yang lain, itu membuat saya ragu terhadap kekiaiannya. Bagaimana tidak, mesti yang terjadi akan sibuk mikirkan bisnisnya dari pada santrinya. Sibuk ngitung uang daripada bangun malam. Kalau sudah begini darimana mau mandhi (mujarab) doanya"

Sehingga dari pemaparan sejumlah subjek penelitian yang berkaitan dengan sosialisasi yang asimetris tentang pengkeramatan terhadap kiai dapat diklasifikasikan sebagai berikut:

\section{Tabel 2}

Faktor Sosialisasi Asimetris Terhadap Pengkeramatan Kiai

Faktor Sosialisasi Asimetris Terhadap Pengkeramatan Kiai

Keterlibatan kiai dalam politik praktis

Keterlibatan kiai dalam bisnis praktis

Kehidupan kiai yang gelamor

Adanya sifat-sifat yang tercela pada kiai; seperti bubuddunya (gemar mengumpulkan kekayaan, senang kehormatan dan jabatan, keras dan mudah menghardik, lebih sering berkumpul dengan para pejabat dan orang kaya daripada santrinya dan orang-orang miskin. 
Klasifikasi ini didasarkan pada kesimpulan subjek penelitian atas refleksi yang mereka peroleh dari stock of knowledge yang diajarkan oleh pesantren tentang ulama-ulama sun' (ulama yang jelek perangainya) sekaligus juga merupakan hasil dari refleksi yang diperoleh melalui interaksi dengan masyarakat sekitar pesantren.

\section{IDENTITAS/PERAN KIAI DALAM MENJAGA SPIRITUALITAS UMAT}

Dialektika masyarakat membentuk bangunan relitas bahwa masyarakat terbagi dalam dua bagian besar yakni masyarakat sebagai realitas objektif dan masyarakat sebagai realitas subjektif. Dalam kaitannya dengan realitas subjektif, identitas merupakan unsur kunci dalam realitas subjektif.

Sebagai sosok yang dipandang keramat; memiliki kharisma dan keahlian di mata masyarakat, dalam realitas air doa dan amalan ini kiai memiliki identitas sebagai pelayan masyarakat yang siap membantu kebutuhan masyarakat tanpa mengharap imbalan atau pamrih. Hal ini dilakukan karena kiai dipandang sebagai individu yang dekat kepada Allah, sehingga perilakunya perlu mencerminkan ibadah; mendekatkan diri kepada Allah. Segala bentuk yang dilakukan kiai adalah dalam kerangka ikhtiar yang dinyatakan sebagai perintah Allah. Motivasi dakwah li i'la kalimatillah adalah kewajiban yang disandang oleh gelar kiai sebagai tanggung jawab kekhususan atas perannya dan keistimewaan yang disandangnya.

Masyarakat datang kepada kiai dengan berbagai keperluan, diantaranya adalah meminta air doa dan amalan. Kebanyakan air doa diminta oleh masyarakat untuk penyembuhan penyakit, tapi ada juga untuk keperluan lain, misalkan untuk kehamilan dan ketika hendak melahirkan. Selain itu ada juga keperluan lain sebagaimana dinyatakan oleh $\mathrm{Zuhri}^{47}$ :

${ }^{47}$ Wawancara pada tanggal (20/12/2019)

At-Turäs: Jurnal Studi Keislaman

E-ISSN: 2460-1063, P-ISSN: 2355-567X

Volume 7, No. 1, Januari-Juni 2020 
"Amalan yang paling banyak diminta adalah untuk masalah ekonomi, kelancaran usaha dan bisnis, juga untuk kegelisahan batin, sampai-sampai ada juga yang tidak bisa tidur; juga masalah hubungan dalam keluarga, suami istri kurang harmonis; masalah keamanan dirinya dan keluarganya; masalah tanaman yang kurang subur; dan ketika membangun dan menempati rumah."

Dalam proses meminta air doa dan amalan ini, juga terjadi penyampaian pesan-pesan yang disampaikan oleh kiai, setelah ablu hajat menyampikan keluh-kesahnya. Dalam pesan-pesannya itu, kiai lah yang berhak menentukan siapa yang pantas diberi "wejangan ini", dan siapa yang pantas untuk diberi "wejangan lainnya". Hal ini terjadi, meski ablu hajat hampir rata-rata memiliki latar belakang santri, alumni atau yang memiliki hubungan dengan Pesantren Nurul Jadid, kenyataannya memiliki pengetahuan yang berbeda-beda dalam keagamaan, sebagaimana yang disampaikan Zuhri ${ }^{48}$ :

"Jadi ketika mereka datang (meminta amalan atau air doa), kalau memang kira-kira mereka awam, ya itu perlu diluruskan, bahwa sebetulnya yang menyembuhkan dan menentukan adalah Allah. Jadi, apapun dan siapapun itu hanyalah media yang dijadikan sabab oleh Allah, dan tentu sabab yang paling pokok dalam ajaran kita adalah doa; memohon pertolongan kepada Allah. Ya soal pakai media-media lain itu tambahan saja saya kira. Yang pokok itu doannya."

Hal ini dibenarkan oleh Firma. Setiap kali ia mendatangi kiai dengan berbagai keperluan, ada wejangan-wejangan yang diterima. Efek dari wejangan itu bagi Firma cukup menenangkan. Berikut pernyataan Firma ${ }^{49}$ :

"Waktu itu saya bermimpi Almarhum Kiai Abdul Haq (Salah satu jajaran Dewan Pengasuh Pesantren Nurul Jadid) mengambil kertas yang jatuh berisi tulisan. Lalu saya bertanya kepada beliau; itu kertas apa? Terus saya dilihat oleh beliau dan mengakatan sesuatu, namun dalam mimpi itu kata yang diucapkan beliau tidak jelas. Akhirnya saya berteguh hati untuk mendatangi beliau. Ternyata belum sampai saya mengutarakan mimpi saya, beliau sudah langsung menyuruh saya untuk mengamalkan bacaan sholawat; Allabumma Sholli Ala Sayyidina Muhammad dengan syarat sebanyak 200 kali, dibaca setiap habis sholat fardlu, tanpa berubah duduk

${ }^{48}$ Wawancara pada tanggal (20/12/2019)

${ }^{49}$ Wawancara pada tanggal $(10 / 12 / 2019)$ 
dan berlangsung selama satu minggu. "nanti kalau sudah selesai, kamu kembali kesini lagi. Amalan apapun yang akan kamu minta nanti akan saya beri," begitu kata beliau. Namun belum sempat beliau—kalau dalam bahasa saya-memenuhi janjinya, beliau lebih dulu meninggal dunia. Merasa Tidak puas, kemudian saya mendatangi kakak beliau (Kiai Zuhri). Karena saya yakin beliau (Kiai Zuhri) bisa mengkomunikasikan dengan arwah Kiai Abdul Haq yang sudah meninggal. Ternyata saya malah ditegur oleh Kiai Zuhri agar tidak berfikir demikian. Lalu, Kiai Zuhri memberikan amalanistighfar dan berpesan agar tidak untuk tujuan duniawi. ...... bertemu dengan kiai saja itu sudah membuat saya tenang. Bahkan saya kalau sudah sumpek-sumpek itu kebanyakan minta nasehat-nasehat ke kiai dengan tujuan untuk mencari ketenangan."

Sehingga dapat dibuatkan klasifikasi Identitas kiai dalam tradisi meminta air doa dan amalan ini sebagai berikut:

\section{Tabel 3}

\section{Identitas Kiai, Keyakinan Masyarakat Dan Fungsi Yang Diyakini}

\begin{tabular}{|c|c|c|}
\hline Identitas Kiai & Keyakinan Masyarakat & $\begin{array}{r}\text { Fungsi } \\
\end{array}$ \\
\hline Guru Spiritual & $\begin{array}{l}\text { Sebagai orang yang dekat } \\
\text { kepada Allah }\end{array}$ & $\begin{array}{l}\text { Dapat membimbing kepada jalan } \\
\text { yang di ridloi Allah }\end{array}$ \\
\hline Ulama & Ahli ilmu agama & $\begin{array}{l}\text { Menuntun masyarakat sadar akan } \\
\text { hukum agama }\end{array}$ \\
\hline $\begin{array}{l}\text { Pimpinan } \\
\text { Masyarakat }\end{array}$ & $\begin{array}{l}\text { Memiliki sifat-sifat keba- } \\
\text { jikan dan mengendalikan } \\
\text { hawa nafsu }\end{array}$ & $\begin{array}{l}\text { Mewujudkan kesejahteraan ma- } \\
\text { syarakat }\end{array}$ \\
\hline Wali Allah & $\begin{array}{l}\text { Diberikan keberkatan oleh } \\
\text { Allah }\end{array}$ & $\begin{array}{l}\text { Untuk menyampaikan keber-katan } \\
\text { Allah kepada masyarakat }\end{array}$ \\
\hline Ahli Metafisis & $\begin{array}{l}\text { Sidik paningale (tajam } \\
\text { penglihatannya) }\end{array}$ & $\begin{array}{l}\text { Untuk mengarahkan kepada hakikat } \\
\text { yang tak diketahui manusia biasa }\end{array}$ \\
\hline Tabib & Doanya mujarab & $\begin{array}{l}\text { Untuk memhonkan kepada Allah } \\
\text { agar diberi kesembuhan }\end{array}$ \\
\hline $\begin{array}{l}\text { Ahli } \\
\text { Numerologi }\end{array}$ & $\begin{array}{l}\text { Mengetahui perhitungan- } \\
\text { perhitungan masa depan }\end{array}$ & $\begin{array}{l}\text { Untuk mendapatkan kebahagia-an di } \\
\text { dunia dan menghindarkan } \\
\text { malapetaka }\end{array}$ \\
\hline $\begin{array}{l}\text { Ahli kejiwaan } \\
\text { dan kebatinan }\end{array}$ & $\begin{array}{l}\text { Sidik peningal serta abli } \\
\text { riyadloh dan mujabadah }\end{array}$ & $\begin{array}{l}\text { Untuk melihat potensi dan } \\
\text { mengembangkan potensi masya- } \\
\text { rakat dalam upaya mencapai } \\
\text { keberuntungan dunia akhirat }\end{array}$ \\
\hline Ahli Primbon & $\begin{array}{l}\text { Mujarab jimat dan amal- } \\
\text { an-amalannya }\end{array}$ & Untuk kesuksesan \\
\hline
\end{tabular}

Namun perlu ditekankan, identitas yang tertera dalam tabel diatas tidaklah mutlak semua dikonstruksi oleh seorang subyek penelitian. Seseorang 
bisa hanya mengkonstruksi beberapa identitas saja; seperti kiai sebagai guru spiritual, ulama dan pemimpin masyarakat, sedang identitas yang lain dia tidak mengkonstruksinya. Sehingga, klasifikasi identitas diatas adalah kesimpulan konstruksi seluruh subyek penelitian, bukan orang perorang.

\section{PENUTUP}

Konstruksi masyarakat kepada kiai dipengaruhi oleh objektifasi nilainilai yang melembaga pada lingkungan keluarga ataupun masyarakat terkait dengan penyemaian tradisi-tradisi yang tidak lepas dari ciri khas jawa sebagaimana telah dibahas sebelumnya. Pengagungan terhadap orang tua dan guru menjadi ciri khas utama tradisi ini. Pengejewantahan tradisi ini terus disosialisasikan oleh oleh orang tua dalam berbagai macam praktek yang telah melembaga sehingga cukup mudah menjadi sumber acuan cadangan sistem pengetahuan dan sistem nilai.

Objektifasi juga terjadi melalui tradisi di pesantren. Praktik sosial di dalam pesantren didasarkan pada ajaran keagamaan yang diyakini kesakralannya. Disamping itu didukung dengan praktek-praktek spiritualitas yang tentunya lebih membekas dibandingkan dengan praktek-praktek simbolis saja. Lagi-lagi dalam praktek spiritualitasnya pun diambilkan dari sumber agama. Sehingga ketersediaan relitas objektif tentang kekeramatan kiai begitu lengkap dan kuat.

Melalui konsep sosialisasi Berger ditemukan bahwa di pesantren terjadi sosialiasi luar-dalam terhadap peng-keramatan terhadap kiai. Sosialisasi itu tidak hanya menyentuh fisik-simbolis tapi lebih dalam kepada kejiwaanemosional dan cara berfikir. Sehingga sulit meruntuhkan, terutama ketika terjadi bangunan sikap kultus kepada kiai. Temuan ini tidak sama dengan yang dinyatakan oleh Berger dan Luckmann, bahwa sosialisasi primer dalam keluarga sulit diruntuhkan dan sosialisasi sekunder diluar lingkungan keluarga mudah untuk diruntuhkan. 
Namun, sebagaimana yang telah dinyatakan dalam diskursus Berger, bahwa tidak selamanya sosialisasi itu berjalan mulus (sosialisasi asimetris). Dalam perjalanannya seseorang akan bersentuhan dengan ketersediannya objektifasi lainnya yang menggugurkan pengkeramatan terhadap kiai. Dari hasil refleksinya terhadap pengalaman bertemu langsung dengan sosok kiai, stock of knowledge, dan interaksinya dengan masyarakat membuahkan konstruksi yang berbeda dari sosialisasi patronase terhadap kiai. Subjek memiliki kecenderungan untuk menyeleksi terhadap kiai yang dijadikan panutan atau patron.

Dari hasil refleksi yang membentuk paradigma seleksi terhadap kiai yang dijadikan panutan, didahului sebelumnya dengan interaksi yang dilakukan dengan keluarga, masyarakat maupun terhadap kiai, hal ini melahirkan identitas yang melembaga dalam struktur sosial. Identitas-identitas yang kemudian dilekatkan pada kiai tidak lepas dari faktor kebutuhan yang tidak boleh tidak dan datang memaksa dalam kehidupan masyarakat. Kebutuhan yang terkait dengan seluruh persoalan hidup itu menarik kepada pencarian identitas yang dapat menyelesaikan persoalannya. Intinya masyarakat butuh sandaran, masyarakat butuh sesuatu yang meyakinkan bahwa persoalannya dan masa depannya bisa diatasi. Karena dalam tradisi masyarakat yang ada dilingkungan Pesantren mengakui bahwa hidup ini seringkali tidak sama dengan penentuan dari diri sendiri, karenanya ada kekuatan ghaib ataupun kekuatan adikodrati yang meliputi. Sehingga membutuhkan penyelesaian dari sosok yang diyakini memiliki kekuatan adimanusiawi dan masyarakat mengidentitaskan itu pada kiai. Identitas inilah yang menjaga dan memelihara struktur sosial hubungan antara masyarakat dan kiai hingga saat ini. 


\section{DAFTAR PUSTAKA}

Abdullah, T. (1983). Agama dan Perubahan Sosial. Jakarta: Rajawali.

Azharghany, R. (2018). Capitalizing The Sacred: Marketing Blessed Water as Religious Theraphy in Krejengan Probolinggo. AT-TURAS: Jurnal Studi Keislaman, 5(2).

Berger, P. L. (1969). The Sacred Canopy: Element of a Sociological Theory of Religion. New York: Anchor Books.

Binder, L. (1960). Islamic Tradition and Politics: The Kijaji and the Alim. Comparative Studies in Society and History, 2(2), 250-256.

Dhofier, Z. (1984). Tradisi Pesantren: Studi tentang Pandangan Hidup Kyai. Jakarta: LP3ES.

Durkheim, E. (1984). The Elementary Forms of the New Religious Life. London: Routledge.

Effendy, B. (1990). Nilai-Nilai Kaum Santri. In D. Raharjo (Ed.), Pergulatan Dunia Pesantren Membangun dari Bawah. Jakarta: P3M.

Elkins, D. N. (1998). Toward a Humanistic-Phenomenological Spirituality Definition, Description, and Measurement. Journal of Humanistic Psychology, 28(4), 5-18.

Geertz, C. (1960). The Javanese Kijaji: The Changing Role of a Cultural Broker. Comparative Studies in Society and History, 2(2), 228-249.

Geertz, C. (1960). The Religion of Java. Illinois: Massachusetts Institute of Technology.

Hosaini, A. (2016). Akulturasi nilai dan budaya dalam sistem pendidikan pesantren. At-turas: Jurnal Studi Keislaman, 3(1).

Huda, M. (2016). Assessing The Relation Between Majority And Minority Groups (A Critical Study on the Spirit of Domination in a Heterogeneous Society). At-Turas: Jurnal Studi Keislaman, 3(2).

Jay, R. R. (1969). Javanese Villagers: Social Relations in Rural Modjokuto. Cambridge and London: MIT Press.

Morris, B. (2003). Antropologi Agama. Yogyakarta: AK Group.

Mulder, N. (2001). Ruang Batin Masyarakat Indonesia. Yogyakarta: LKIS.

Munif, M. H. (1992). Pondok Pesantren Berjuang. Surabaya: Sinar Wijaya.

Nahdiyah, H. (2017). Menggugah Keberadaan Pesantren Untuk Membangun Nalar Pendidikan Berbasis Local Wisdom: Suatu Tela'ah Eksploratif 
dalam Perspektif Budaya. AT-TURAS: Jumal Studi Keislaman, 4(2).

Noer, D. (1973). The Modernists Muslim Movement in Indonesian 1900-1942. London: Oxford University Press.

Seligman \& Peterson. (2004). Character Strengths and Virtues. In A Handbook and Classification. New York: Oxford University Press.

Siradj, S. A. (1998). Ahlus Sunnah Wal Jama'ah dalam Lintas Sejarah. Jogjakarta: LKPSM.

Steenbrink, K. A. (1986). Pesantren, madrasah, sekolab: pendidikan Islam dalam kurun moderen. Jakarta: LP3ES.

Usman, S. (1991). The Structural Interction of Elite Groups in Defelopment. Makalah Pada Forum Asean Muslim Social Scientist.

Walcoot, E. (2004). Seni Pengobatan Alternatif Pengetahuan Dan Persepsi. Malang: Universitas Muhammadiyah Malang. 